\title{
THE COGNITIVE-COMMUNICATIVE DIMENSION OF THE REPRODUCTION OF CULTURAL INFORMATION IN LITERARY TRANSLATION
}

\author{
Liashenko Tetiana \\ Phd Professor, Associate Professor \\ ORCID ID 0000-0001-9751-2173 \\ Ivan Franko National University of Lviv \\ Universytetska Str., 1, 79000, Lviv, Ukraine \\ laschenko_t@yahoo.de
}

The paper highlights the strategies of reproduction of cultural specific information and overcoming cultural differences on the material of German translation. As the methodological basis for defining strategies of reproducing cultural information serves the definition of translation as a unity of process and result, as a cognitive-communicative activity that unfolds in a three-phase process - interpretation of the megaconcept of the original, modeling of the megaconcept of translation, and its implementation at the text level. To outline the integrative conceptual image of the original, the method of field modeling of the concept has been applied. The conceptual, image and value components of the hierarchical structure of a megaconcept of the work have been characterized. The transfer of the conceptual image of the original onto the worldview of the German language revealed the differences and lacunarity of cultural information as well as divergence of its value interpretations. As a result of the study, the foreignization was identified as a global strategy for preserving the cultural component of the original text. On the material stated the problems of translation, connected with reproduction of cultural information were studied. The primary focus is on the reproduction of realia, imagery, dialect, national specifics of emotions and overcoming the temporal distance. The correlation between the use of the local strategies of domestication and estrangement and the nature of cultural information reproduction problems was investigated. The tactics and techniques of translation of culturally specific elements of the text were identified.

Key words: global translation strategy, cultural-specific information, local translation strategy, megaconcept of the work, translation problem.

\section{КОГНІТИВНО-КОМУНІКАТИВНИЙ ВИМІР ВІДТВОРЕННЯ КУЛЬТУРНОЇ ІНФОРМАЦІЇ В ХУДОЖНЬОМУ ПЕРЕКЛАДІ}

\section{Ляшенко Тетяна}

кандидат філологічних наук, доцент

ORCID ID 0000-0001-9751-2173

Львівський національний університет імені Івана Франка

вул. Університетська, 79000, Львів, Україна

laschenko_t@yahoo.de

У статті підлягають розгляду стратегії відтворення культурної інформації $i$ подолання культурних розбіжностей на матеріалі німецького перекладу. Методологічною основою визначення стратегій відтворення культурної інформації $\epsilon$ тлумачення перекладу як єдності процесу й результату, як когнітивнокомунікативної діяльності, яка розгортається в трифазному прочесі - інтерпретація мегакониепту оригіналу, моделювання мегаконцепту перекладу та його реалізація на

(C) Liashenko T., 2020 
текстовому рівні. Для окреслення інтегративного конщептуального образу оригіналу застосовано методику моделювання структури текстового концепту. Охарактеризовано понятійний, образний $i$ иіннісний компоненти ісрархічної структури мегаконщепту твору. Проєктування конщептуального образу оригіналу на картину світу німецької мови дозволило виявити незбіги щзодо культурної інформації, розбіжність ї̈ иіннісних інтерпретацій. У результаті проведеного дослідження глобальною стратегією збереження культурної інформації оригіналу визначено очуження. Розглянуто проблеми перекладу, пов'язані із відтворенням культурем. Увагу зосереджено на відтворенні реалій, засобів образності, діалекту, національної специфіки емочій, подолання часової дистаниії. 3'ясовано співвідносність застосування локальних стратегій одомашнення й очуження з характером проблем відтворення культурної інформачії. Визначено тактики та прийоми перекладу культурем у тексті оригіналу.

Ключові слова: глобальна стратегія перекладу, культурна інформація, культурема, локальна стратегія перекладу, мегаконцепт твору, проблема перекладу.

\section{Вступ}

За останні десятиліття теорія перекладу здійснила культурологічний поворот і почала розглядати переклад як «перехрестя культур», як репрезентацію інших культур. У руслі «культурного повороту» одиницею перекладу вважають не слово й навіть не текст, а культуру (Bassnett, Lefevere, 1998) як семіотичне утворення в результаті процесів трансформації, присвоєння й маніпуляції (Prunč, 2011: 279). Проте, на думку культурологині Дорис Бахманн-Медик, дискусійним залишається питання меж одиниці культурного перекладу: підлягають перекладу культури як цілісні системи, лише певні їі фрагменти чи ключові поняття? Постає також питання форм проявів культурної інформації, у яких знаходять відбиття світосприйняття, спосіб мислення та моделі поведінки представників певної лінгвокультурної спільноти. Важливу роль у розкритті окреслених питань відіграє художній переклад. Виявлення й інтерпретацію культурної інформації уможливлює аналіз культурем у художньому тексті лише із урахуванням соціально-історичного й культурного макроконтексту (Bachmann-Medick, 2009: 242-243).

Наукова новизна - уперше підлягає розгляду проблема відтворення культурної інформації в когнітивно-комунікативному вимірі на матеріалі німецького перекладу.

Об'єкт дослідження - культурна інформація в художньому тексті.

Предмет дослідження - перекладацькі стратегії, тактики та прийоми відтворення культурної інформації тексту оригіналу.

Мета статті - продемонструвати застосування перекладацьких стратегій, які дозволяють відтворити культурну специфіку й подолати культурні розбіжності в художньому перекладі на матеріалі німецької мови. Для досягнення мети зосередимося на розв'язанні таких завдань: 1) визначити глобальну стратегію перекладу оповідання 3 народного життя: «Таку вже Бог долю судив» Михайлини Рошкевич; 2) розглянути на зазначеному матеріалі проблеми перекладу, пов'язані із відтворенням культурної інформації; 3) встановити локальні стратегії, тактики та прийоми, які застосовано для розв’язання окреслених проблем перекладу культурної інформації.

\section{Матеріали та методи дослідження}

Методологічною основою визначення стратегій відтворення культурної інформації $\epsilon$ розуміння перекладу як когнітивно-комунікативної діяльності та концепція перекладу як трифазного процесу, який за Т. Андрієнко складається 3 1) фази трансформування мовної семантики вихідного тексту в когнітивну структуру інтегративний концептуальний образ оригіналу (мегаконцепт); 2) фази проектування концептуального образу вихідного тексту на картину світу мови перекладу, що дозволяє виявити зони спільного (універсального) та відмінного (культурноспецифічного), визначити глобальну стратегію перекладу та змоделювати 
концептуальну структуру цільового тексту; 3) фази реалізації мегаконцепту цільового тексту на текстовому рівні. На цьому етапі відбувається визначення локальних стратегій, тактик та прийомів перекладу з метою втілення концепту цільового тексту в його мовній реальності (Андрієнко, 2017: 140).

Опираючись на тлумачення перекладу як єдності процесу й результату, виявляємо за текстом перекладу як готового продукту головні кроки перекладацького процесу, а саме: визначення проблем перекладу, обрання стратегій та тактик, прийняття перекладацьких рішень. Шляхом аналізу мовної семантики й соціальноісторичного та культурного макроконтексту оповідання «Таку вже Бог долю судив» Михайлини Рошкевич визначено цілісний мегаконцепт твору. Згідно $з$ методикою польового моделювання концепту такий інтегративний концептуальний образ оповідання $\epsilon$ ієрархічною структурою 3 понятійним, образним i ціннісним компонентами. Його проєктування на картину світу німецької мови дозволило виявити можливі незбіги, розбіжність ціннісних інтерпретацій, унаслідок чого в перекладача виникає орієнтовний концептуальний образ цільового тексту й програма його реалізації - глобальна стратегія перекладу. У результаті співвіднесення концептуального образу цільового тексту з його мовною реалізацією визначено локальні стратегії, спрямовані на відтворення фрагментів тексту, що містять культурну інформацію. Стратегії реалізує відповідний комплекс тактик, які визначають прийоми перекладу культурем як одиниць культурної інформації, представленої в тексті оригіналу.

\section{Обговорення}

Однією з найактуальніших проблем перекладу дослідники вважають збереження лінгвокультурологічного аспекту вихідного тексту в процесі перекладу, оскільки сприйняття інформації пов'язано з культурним контекстом діяльності людини, його досвідом. Міжкультурна асиметрія зумовлює пошуки нових дієвих механізмів відтворення лінгвокультурної специфіки світобачення, способу мислення, які зокрема пропонують когнітивна лінгвістика й лінгвокультурологія. Вивченню проблеми присвячені лише поодинокі дослідження, зокрема здійснено спробу побудувати лінгвокультурологічну модель перекладу, орієнтовану на врахування лінгвокультурної специфіки в перекладі (Свтеев, 2014), досліджено стратегії перекладу як когнітивний регулятив перекладацького дискурсу (Андрієнко, 2017). У царині німецької мови застосування лінгвокогнітивного й лінгво-(етно-)культурного підходів проілюстровано на матеріалі німецьких фразеологізмів (Редчиць, Багач, 2013).

\section{Результати дослідження}

Уперше проілюстровано застосування перекладацьких стратегій відтворення культурної інформації і подолання культурних розбіжностей на матеріалі німецького перекладу. Матеріалом дослідження слугувало оповідання «Таку вже Бог долю судив» Михайлини Рошкевич, беззаперечний культурний об'єкт у літературі Галичини кінця XIX століття, яке відбиває численні тексти культури того часу: традиції, звичаї, мисленнєві й поведінкові шаблони, закодоване в мові світосприйняття, предмети побуту, пісенний фольклор. 3 метою створити в перекладі концептуальний образ твору - нелегкої жіночої долі в невеликому гірському селі на теренах Галичини наприкінці XIX ст. - та відтворити національно-культурну самобутність тогочасного сільського життя глобальною стратегією перекладу обрано стратегію очуження. Глобальній стратегії збереження культурного компоненту тексту оригіналу в перекладі підпорядковані локальні стратегії, співвідносні 3 характером проблем відтворення культурної інформації в оповіданні. До таких відносимо відтворення реалій, засобів образності, діалекту, а саме бойківської говірки, національної специфіки емоцій, подолання часової дистанції.

Оповідання «Таку вже Бог долю судив» Михайлини Рошкевич входило до жіночого альманаху «Перший вінок» 1887 року, який, на думку I. Франка, належав до 
«найкращих і найбагатших змістом наших видань 3 того десятиліття» (Франко, 1984: 496). Переклад оповідання опубліковано в антології української жіночої літератури «Сестро, одягни крила! Жіночі голоси з України». Поставивши за мету ознайомити німецькомовного читача 3 творами найяскравіших представниць української літератури - від іiї початків до сьогодення, перекладачі намагалися відтворити в перекладі лінгвокультурну специфіку оригіналів. Історія, яку оповідає Михайлина Рошкевич, на думку сучасника письменниці Михайла Павлика, «найправдивіша (найреальніша) і своєю правдою найстрашніша з усього, що надруковано в «Вінку»» (Павлик, 2012: 230). В оповіданні змальовано важку жіночу долю селянки Марійки Оленючки, яка у віці 36 років залишила цей світ. Ї̈̈ трагічну історію переповідає подруга небіжки. Марійка змушена була виконати волю батька й вийти заміж за нелюбого, але заможнішого чоловіка. Свого коханого Марійка забути не змогла, за що зазнавала знущань 3 боку чоловіка. Нещасливе подружне життя, важка робота й побиття вкоротили життя молодої жінки.

Аналіз інтегративного концептуального образу оповідання і його відтворення в перекладі свідчить про відсутність істотних змін понятійного компоненту мегаконцепту твору. У перекладі переважно збережено змістовно-фактуальну інформацію: сюжет і композицію, кількість персонажів, їхні демографічні (вік, стать) характеристики. Щоправда, змін зазнали певні соціальні (втрата бойківського діалекту) ознаки дійових осіб. Незбіги або лакунарність у відтворенні асоціативно-образного компоненту мегаконцепту оповідання зумовлені розбіжностями в картинах світу української й німецької лінгвокультур, а також поповненням чи змінами таких картин світу 3 часом. Так, змінилися деякі образні характеристики персонажів (напр., зовнішності) та художні деталі оригіналу. Крім того, відмінні соціокультурні й історичні асоціації в представників обох лінгвокультур викликають ужиті в тексті оповідання предметні й насамперед когнітивні реалії. Ціннісний компонент концепту оповідання становить його ідейний зміст (підлеглість і другорядність української селянки в сімейному житті), суспільно-політичне значення (реалістичне зображення недолі селянок та активізація українського жіночого руху на теренах Галичини) художня цінність (реальні картини народного життя, правдиве відтворення сповненої принадної краси й душевного благородства селянської душі, утілена в пісенному фольклорі народна мудрість). Співвіднесення ціннісних орієнтирів української та німецької лінгвокультур, за якими підлягають оцінці персонажі, їхні вчинки та певні події оповідання, свідчить про спільність головних цінностей культур, що мають християнське коріння: вірність у коханні, щирість у дружбі, співчуття людині, яку спіткало горе та ін. Проте у відтворенні оцінно-ціннісного змісту оригіналу не вдалося уникнути втрат, пов'язаних зокрема 3 інтенсивністю чи експресивністю оцінки. Зауважимо, що асоціації та оцінна інтерпретація зумовлені не лише текстом, а й досвідом інтерпретатора, його мовною картиною світу; вони $€$ водночас індивідуальними й соціально зумовленими, такими, що грунтуються на цінностях, віруваннях та естетичних смаках суспільства.

Свій твір Михайлина Рошкевич охарактеризувала як народне оповідання. Однією із класифікаційних ознак цього жанру літературознавці вважають прикріпленість до локальної історичної і соціально-побутової реальності, що зумовлює конкретність і документальність викладу. Оповідь у творі Михайлини Рошкевич ведеться від імені учасниці зображуваних подій, Фенни Лучківни, яка реально проживала в селі Лолин і гарно виконувала народні пісні. Михайлина Рошкевич правдиво зобразила життя в гірському селі Галичини кінця XIX ст., про що свідчить зокрема використання бойківського діалекту, на якому розмовляють персонажі; предметні реалії, що відтворюють побут; традиції, пов'язані з інститутом сім'ї та ролі жінки в ньому; весільні й поховальні звичаї та обряди селян. Задля полегшення сприйняття оповідання авторка коментує багато реалій безпосередньо в тексті та у виносках. 
Серед численних слів-реалій оповідання виокремлюємо предметні, співвіднесені з конкретним об'єктом матеріального світу української лінгвокультурної спільноти, й когнітивні, під якими розуміємо культурно-специфічні концепти та культурні сценарії. Предметні реалії в тексті оповідання позначають предмети побуту селян (запічок, торбинка), житло й господарські будівлі (курна хата, обійстя, стодола, стайня, кошара, оборіг), їжу (комашня) та напої (горілка), одяг (рантух, рубатка), рослини (смерічка), одиниці виміру (цілий трунт, чвертина вівса, клин полотна), антропоніми та топоніми. Перекладачі оповідання прагнули ознайомити німецькомовного читача зі специфікою національно-культурного життя селян у Галичині наприкінці XIX cт., не обтяжуючи його сприйняття додатковими когнітивними зусиллями. Тому під час перекладу предметних реалій задля збереження національного й локального колориту локальну стратегію очуження застосовано помірковано, переважно відносно антропонімів і топонімів. Стратегію очуження реалізує тактика відтворення форми й конотацій екзотичності, яка створює ефект занурення в іншомовне та іншокультурне середовище шляхом транскрипції/транслітерації: Marijka, Fenna, Wasyl, Adam, Olena, Byrtschak, Olenjuk, Schutkow; Zholobky, Lolyn.

Для більшості предметних реалій у перекладі обрано локальну стратегію одомашнення з опорою на мовну картину світу німецької лінгвокультури, яку реалізує тактика відтворення денотативного змісту шляхом заміни реалії на аналог у цільовій культурі: стодола - eine Scheune, обороги - Schober, торбинки - Knappsack, nо чвертині вівса - je zwei Sester Hafer, рубатя - Brautkleid. Денотативний зміст реалії передано також за допомогою описового перекладу: xama курна - Haus ohne Rauchabzug. Такі заміни полегшують німецькомовному читачеві прочитання тексту, сприяють повному розумінню смислу. Слово-реалію ицілий грунт, що передає майнові відносини селян Галичини, передано за допомогою буквального перекладу в супроводі 3 пояснювальним перекладом у підрядковій виносці.

Когнітивні реалії відбивають особливості світосприйняття та сценарії поведінки певної лінгвокультури, які можуть бути недоступні безпосередньому спостереженню й не завжди експліковані в тексті. Проблема перекладу когнітивних реалій полягає в тому, що певне явище або ситуація можуть існувати й мати номінації в обох лінгвокультурах, проте їхнє асоціативне поле може бути відмінним. До когнітивних реалій оповідання відносимо: народні свята й обряди (вечорнищі, м'яснищі, сватів слати, іти „на сторону“, віно, „іти на смерть“), реалії суспільного (війт) і церковно-релігійного життя (ксьондз, прошу єгомостино $і$ ласки, при протоколі питають), види праці (шарварок), фольклорні реалії (сирітські пісні), сентенції (Таку вже Бог долю судив, Як то Бог дає).

Під час перекладу когнітивних реалій з метою відтворити головні ознаки референтної ситуації переважно застосовано стратегію одомашнення. Для повного розуміння зображуваної ситуації українські лінгвокультурні концепти та культурні сценарії замінено німецьким аналогом (на ц̧ілу ніч „іти на смерть “ - die ganze Nacht Totenwache halten zu können), передано описовим перекладом (Уплескали тоту нещасливу сватьбу - So kam man bei dieser unglücklichen Brautwerbung per Handschlag überein), відтворено за допомогою експлікації смислу (зачали ладнати сирітськоі hoben da an, Klagelieder über das böse Schicksal zu singen).

3 метою компенсувати повну або часткову втрату національно-культурного колориту після аналогів слів-реалій, пов'язаних з традиціями та звичаями укладання шлюбу або поховання, наведено в дужках їхні транслітеровані форми (помірне одомашнення), які вже зафіксовані в інших етнографічних текстах: Hochzeitsführerinnen (Swachy), Brautwerber (Starost). Прикладом помірного очуження слугує переклад форми громадського дозвілля сільської молоді «вечорниці». У тексті перекладу цю реалію транслітеровано й розтлумачено за допомогою описового перекладу в дужках: Wetschornyci (gesellige Abende). 
3 перекладом предметних і когнітивних реалій пов'язана проблема подолання хронологічної часової дистанції між оригіналом і перекладом. Оповідання як архаїчний текст створений сучасною на той час мовою. Наявність історизмів i застарілої лексики в тексті не є частиною авторського задуму чи художнього хронотопу, а $є$ свідченням явищ життя кінця XIX століття в Галичині. Здійснюючи переклад більше як через століття, перекладачі вдавалися до стратегії архаїзації, яка полягає у створенні образу минулої епохи двома шляхами: у межах стратегії очуження через запозичення історичних реалій мови оригіналу (Komaschnja, Swachy, Starost, Wetschornyci) або одомашнення через залучення історичних реалій, когнітивних i прагматичних аналогів із картини світу мови перекладу. Так, слово-реалія на позначення родинних зав'язків стрийко (брат батька), перекладено застарілим словом Oheim (материн брат), денотативне значення якого відмінне від оригіналу. Значення спорідненості саме по лінії матері не є в цьому фрагменті тексту домінантою змісту, тому задля збереження конотації архаїчності відбулася заміна на слово з відмінним референтом.

У перекладі оповідання застосовано також стратегію адекватної модернізації, тобто адаптації перекладу на мовно-стилістичному, когнітивному та прагматичному рівнях до сучасної мови, картини світу та норм спілкування (Андрієнко, 2017: 368) німецької мови. На мовностилістичному рівні «осучасненню» перекладу оповідання сприяє зокрема заміна застарілої й стилістично забарвленої з погляду сучасного читача лексики на сучасні слова німецької мови: молодиия - Frau, недуга - Krankheit, віщувати - ahnen lassen та ін. На прагматичному рівні модернізація виражається в заміні архаїчних прагматичних формул на сучасні, напр., застарілих діалектних вигуків: $2 a-a c h$ was, $б a-e i$, овва - pah та ін. На когнітивному рівні, а саме когнітивно-регулятивному, модернізацію здійснено шляхом залучення сучасних комунікативно-когнітивних структур, наприклад, правил мовленнєвої поведінки. В оповіданні зустрічаємо архаїчне етикетне звертання до ксьондза прошу єгомостиноі ласки, егомостеньку («єгомость» від «його милість»), яке свідчить про особливу повагу християн до духовних осіб. 3 метою відтворити сценарій «етикетна поведінка в спілкуванні зі священником» у перекладі замінено застарілі мовленнєві формули на формулу сучасного мовленнєвого етикету німецькомовної лінгвокультури $\mathrm{Herr}$ Pfarrer.

У перекладі застосовано в окремих випадках локальну стратегію нейтралізації часової та історичної дистанції, яку реалізує тактика передачі смислових характеристик без маркерів часу. Наприклад, історизм війт в оповіданні означає людину, яка в Галичині в складі Австро-Угорщини очолювала сільську громаду. Ураховуючи історичний часопростір і наявність аналогу Vogt в німецькій лінгвокультурі, у перекладі обрано відповідник без ознак часу Gemeindeälteste з метою уникнути помилкової прив'язки до соціально-історичного контексту середньовічної Німеччини.

Іншу проблему перекладу оповідання Михайлини Рошкевич становить відтворення такого маркеру культурно-історичної інформації як діалект. Твір авторки належить до одного з нечисленних зразків літератури в Галичині з використанням мовних зразків гірської частини Бойківщини. Оповідання написано живою українською мовою, воно зберегло колорит та архаїку персонажів-бойків. Ознакою архаїчності тексту є використання в його мовній тканині бойкізмів: коршма (корчма), дуже нині змаргав ся коло отави (змарганий - змучений, замордований), пристайство (приставання в прийми до жінки), напудитися (налякатися), мамляти (неохоче їсти), пирити (ганьбити, засуджувати), затягнув домів (додому), кілько та ін. До перекладу діалектизмів застосовано в межах стратегії модернізації зокрема тактику добору сучасних відповідників 3 нейтральними (пирити - verärgert sein) або розмовними стильовими характеристиками (пестити - verhätschelt werden).

Проблема перекладу засобів образності полягає в тому, що метафоричне осмислення об'єктивної дійсності пов'язане 3 особливостями світосприйняття та 
менталітету певної лінгвокультурної спільноти. На думку Н. Арутюнової, мовці швидше самі створюють, ніж виявляють подібність між конкретними й абстрактними об'єктами, як наслідок, представники різних лінгвокультур по-різному метафорично осмислюють ідентичний фрагмент дійсності (Арутюнова, 1990: 296-297). Лев Цибатов уводить для метафоричних стереотипів поняття когнітивний стереотип відображення лінгвокультурної спільноти (Zybatow, 2011: 43-44). Когнітивні дослідження метафори та іiі перекладу вказують на різні види міжмовної відповідності за такими критеріями: 1) умови метафоричного картування (спільні/відмінні); 2) лексичного наповнення (однакове/різне) та 3) наявності метафори в мові оригіналу або перекладу. У зв'язку з цим нідерландська дослідниця Неллі Стіенстра розрізняє три групи метафор: 1) культурно-специфічні, 2) характерні для кількох культур і 3) універсальні метафори (Schäffner, 1999: 284). Наявність універсальних метафор дослідниця пояснює спільним фізичним досвідом людей, який певна лінгвокультура може в особливий спосіб структурувати в специфічних концептах. Отже, культурно-специфічною $є$ не сама концептуальна метафора, а iii мовне втілення. У перекладі метафор важливу роль відіграє також ступінь узуалізації метафори (стерті, клішовані, індивідуальноавторські). Перекладність метафори визначає не її «сміливість» чи «оригінальність», а швидше той діапазон, у якому мовець мови перекладу може мати відображені в метафорі спільний культурний досвід і спільні семантичні асоціації (Schäffner, 1999: 281-282). Л. Цибатов уважає правомірним припущення, що авторські метафори в поетичному чи художньому тексті переважно легше перекладати, ніж узуальні метафори, оскільки останні є конвенційними, культурними моделями концептуалізації світу (Zybatow, 2011: 51-52).

В оповіданні зустрічаємо головно узуальні метафори, порівняння та метонімії, що, очевидно, зумовлено жанровою приналежність твору. Оповідь веде типова представниця українського селянства Галичини, мова якого відбиває віковий життєвий досвід пращурів. Для відтворення концептуальних метафор у перекладі застосовано стратегію одомашнення, яку реалізує насамперед тактика відтворення художньої форми шляхом реметафоризації. У випадку заміни українських метафор на співвідносні німецькі відбувається наближення концептуального простору оповідання до картини світу німецької лінгвокультури, що сприяє кращому розумінню й реалізації відповідного прагматичного впливу: єго мати спить уже вічним сном - seine Mutter war für immer eingeschlafen. Приклад ілюструє подібне метафоричне картування (СМЕРТЬ - $\mathrm{COH),} \mathrm{проте} \mathrm{різну} \mathrm{мовну} \mathrm{реалізацію,} \mathrm{яка} \mathrm{полягає} \mathrm{у} \mathrm{відмінності}$ акціонального значення «стан - зміна стану». У німецькій мові зустрічається вираз «спати вічним сном» (den ewigen Schlaf schlafen), проте більш уживаною є ідіома für immer einschlafen (заснути назавжди), яка еквівалентна українській щодо конотації уживаності. В основі українського метафорично-метонімічного виразу жаль кроїть серие лежать кілька концептуальних метафор: АБСТРАКТНЕ ПОНЯТТЯ - ЛЮДИНА та ЛЮДИНА - СЕРЦЕ. У першому випадку персоніфікований емоційний стан жалю асоціюється 3 кравцем. Сама людина представлена метонімічно іiї життєво важливим органом. В українській лінгвокультурі концепт СЕРЦЕ втілений у кількох образах: серце - тканина (кроїти/розривати серце), серце - крихкий предмет (розбити серце). Тоді як для образу серця як тканини концептуальний референт відповідає дійсності м'язи, а отже, і серце можна різати, його образ як крихкого предмету є «хибною» метафорою. Німецькій лінгвокультурі властиве подібне метафоричне картування, проте іiі представники асоціюють людське серця лише 3 крихким предметом. У перекладі вираз жаль кроїть серие відтворено німецькою конвенційною метафорою Kummer bricht das Herz.

Серед засобів образності зустрічаємо характерні для фольклорної мови усталені епітети. Ці одиниці відбивають культурно-історичні традиції українського народу та зберігають у мові народнопісенний колорит. Когнітивною основою постійного епітету в словосполученні рісні сльози (рясні сльози) є метафоричне картування СЛЬОЗИ ДОЩ. Подібне картування спостерігаємо і в німецькій лінгвокультурі, проте 3 
відмінним лексичним наповненням dicke Tränen. Український сталий епітет виник внаслідок сприйняття людиною явища природи, а саме дощу, за ознакою кількості (рясний, який має велику кількість), тоді як у німецькій лінгвокультурі наголошується ознака розміру (dick - von beträchtlichem, mehr als normalem Umfang). Наведені вище приклади доводять тезу про універсальний у більшості випадків характер фізичного досвіду людей, який проте може в особливий спосіб структуруватися в специфічних концептах, тобто мовна реалізація якого може різнитися в український і німецький лінгвокультурах.

Приказка Таку вже Бог долю судив, яка є назвою та лейтмотивом оповідання, за своїм метафоричним і символічним значенням співставна 3 німецькою приказкою das Schicksal lag in Gottes Hand, яку запропоновано в німецькому перекладі. Цей приклад демонструє спільні вірування християни упродовж віків у те, що все робиться з Божої волі і людина не завжди впливає на перебіг подій у житті.

Стратегію одомашнення може супроводжувати також тактика відтворення змісту за допомогою прийому деметафоризації. Метафоричне порівняння ходить як блудна вівия $з$ картуванням ЛЮДИНА - ТВАРИНА відтворено в німецькому перекладі стертою метафорою sie lief wie verloren herum зі спільною когнітивною основою: безпорадна людина - людина, яка збилася з правильного шляху, відбилася від свого оточення, сім'ї і т. ін. У випадку відсутності в мові перекладу подібного за когнітивною основою метафоричного виразу можливе описове відтворення смислу. Так, персоніфікацію роздав ся голос иерковного звона з картуванням НЕЖИВИЙ ПРЕДМЕТ - ЛЮДИНА у перекладі передано неметафоричним виразом erklang die Kirchenglocke.

Розбіжності в способах метафоричного картування, що зумовлені особливостями концептуалізації дійсності в українській та німецькій лінгвокультурах, особливо помітні в компаративних фразеологізмах. Стійкі народні порівняння можуть відбивати естетичні уподобання представників певної лінгвокультури, увиразнювати психологічний портрет персонажу. Так, в оповіданні зустрічаємо порівняння із зоонімом очи великі, сині, а веселі, як у ястряба (картування ЛЮДИНА - ТВАРИНА), яке свідчить про красу й веселу вдачу головної героїні. Таке порівняння вродливої жінки із хижим птахом $є$ чужим для німецької лінгвокультури. Німецькомовний мовець асоціюватиме ознаку життєрадісності швидше з гарним ранком, наприклад, у німецькій мові зустрічається вислів-побажання з нагоди дня народження Heiter wie ein schöner Morgen, soll dein Leben sein! Таким чином, українську конвенційну метафору замінено на німецьку із картуванням ЛЮДИНА - ЯВИЩЕ ПРИРОДИ: Die Augen groß, blau, und heiter wie der Morgen. Ще один приклад демонструє аналогічну розбіжність метафоричного картування: ЛЮДИНА - ТВАРИНА в українській лінгвокультурі й ЛЮДИНА - ЯВИЩЕ ПРИРОДИ в німецькій. За допомогою стійкого народного порівняння ...отець небіжки, сивий як голуб,... охарактеризовано зовнішність старшої людини. Німецька лінгвокультура не порівнює сиве волосся людини 3 сіро-білим пір'ям голуба чи будь-якого іншого птаха. У ï представників сивина людини викликає семантичні асоціації, наприклад, із білим кольором градин, які представлені в складеному прикметникові: ... Vater der Verstorbenen, schlohweiß.... В обох наведених прикладах джерелом компаративних фразеологізмів слугує природа, проте концептуальним корелятом, що залучається для порівняння в українській лінгвокультурі слугує тваринний світ, а в німецькій - явища природи.

Із перекладом культурної інформації тісно пов'язана проблема відтворення національної специфіки емоцій. На думку I. Голубовської, «саме сфера екстралогічного в сприйнятті дійсності тим чи іншим етнічним колективом, сфера емотивно-оцінної діяльності етнічної свідомості створюють неповторність і національну унікальність мов світу» (Голубовська, 2004: 9). Одним із характерних мовних виявів специфіки українського національного світовідчуття, «кордоцентричності» української психічної структури дослідниця вважає вживання демінутивних суфіксальних форм. В оповіданні зустрічаємо чимало таких прикладів: Господочку, сирітка, небіжечка, вороженьки, колосєчко, волосєчко, очка, яблінка, 
миленький, зелененький, вороненький та ін. Хоча демінутиви притаманні німецькій мові, вони не настільки поширені в експресивно-емоційній функції. Дослідники пояснюють це низькою контекстністю комунікативного стереотипу німецького етнокультурного соціуму, коли більше звертають увагу на те, що сказано, ніж на те, як це сказано. Певну роль відіграють також культурно зумовлені правила демонстрації емоцій, які в німецькій культурі передбачають більшу стриманість зовнішнього прояву й мовного вираження емоційного ставлення (Стефаненко, 1990: 163).

Орієнтація на конвенції мовленнєвої взаємодії німецької лінгвокультури в межах стратегії одомашнення дозволяє відтворити головні ознаки референтної ситуації, необхідні для сприйняття емоцій. Відтворення емоційних мовних засобів у перекладі оповідання реалізують тактики відтворення прагматичного потенціалу або смислових ознак висловлення. 3 метою відтворити прагматичний ефект емоційні вигуки-звернення із використанням демінутивів, які відбивають вірування, сценарії поведінки й інтерпретації дійсності селян, замінено на функціональні відповідники: Богочку! - Mein Gott!; Господочку! - Herr des Himmels! Демінутивну суфіксацію як синтетичний засіб вираження емоцій суму, горя, страху, співчуття й уболівання замінено аналітичними засобами німецької мові, які, на жаль, неповною мірою передають експресивно-емоційний потенціал оригіналу. Так, утрату експресивнооцінного значення демінутивної форми о Богочку, о Таточку в перекладі компенсовано за допомогою особового займенника 1-ї особи множини й емоційно-оцінного прикметника O Gott, unser lieber Vater! В окремих випадках перекладачам вдалося замінити українські демінутивні форми на адекватні в смисловому та функціональному плані німецькі демінутиви (очка - ̈̈uglein; любко - mein Liebchen).

Проте здебільшого прагматичний ефект емоційних демінутивів у перекладі втрачено, їх передано в межах тактики відтворення смислових ознак висловлення нейтральним еквівалентом (небіжечка - die Verstorbene; щ⿻о недільки - jeden Sonntag; миленький - mein Lieber), за допомогою смислового перекладу (сирітка - die Arme, das arme Kind; вороженьки - böse Leute) або взагалі вилучено (Богочку, як зачали ото нині звонити по єі душеньйі... Mein Gott, als die Glocke heute ihren Tod verkündete).

Інші вигуки й вигукові фразеологізми, що сигналізують різні вияви станів і почуттів також передано функціональними аналогами, що дозволяє здійснити співставний $з$ оригіналом вплив на читача: Йой! - за молодою, нема молодої - Du liebe Güte! - man schaute nach der Braut, sie war nicht da. (здивування); Га, як би була ураз слухала єго... - Ach was, wenn sie von vornherein auf ihn gehört hätte... (обурення, невдоволення); Eй, бій ся Бога, Фенничко, біжи ми по Mapiŭку! - Um Himmels willen! Liebe Fenna, hol mir Marijka! (вигук-благання); най ci преч каже - Gott behüte (хай не повториться, не при хаті згадуючи - фразу вживають, коли говорять про смерть, недугу).

Вигуковий фразеологізм не снив би ся відтворено в перекладі за допомогою двох прийомів: функціонального відповідника та смислового перекладу. Цей вигукпрохання свідчить про страх перед померлими, які, за народними уявленнями, можуть покликати за собою в інший світ. Хоча представникам німецької лінгвокультури властиве побоювання побачити небіжчика уві сні, його не зафіксовано в мові. Коли носії німецької мови говорять про щось небажане або страшне, вони насамперед просять захисту в Бога й використовують вислів Bewahre/behüte uns Gott vor. Для передачі загального референційного значення вислову - небажання побачити уві сні небіжчика - застосовано також смисловий переклад Bewahre uns Gott vor einem Traum von. У такий спосіб переклад наближено до соціокультурного сценарію поведінки галицьких селян - при згадуванні померлого використовувати вигук-прохання не снив би ся. Таким чином у мовну й концептуальну картину світу представників німецької лінгвокультури долучено нову інформацію, що вимагає від німецькомовного читача додаткових когнітивних зусиль: ...старий небіжчик (не снив би ся!) - der alte verstorbene Byrtschak (Bewahre uns Gott vor einem Traum von ihm!). Такий переклад можна вважати помірним одомашненням. Деякі емоційні вигуки в перекладі вилучено 
й компенсовано емоційно-експресивними частками: ... $\underline{\sigma a}$, xmo ce yмep? - Wer ist $\underline{\text { denn }}$ gestorben?

\section{Висновки та перспективи}

Співставлення понятійного, образного й ціннісного компонентів інтегративного концептуального образу оповідання «Таку вже Бог долю судив» Михайлини Рошкевич та їх відтворення в перекладі німецькою мовою дає підстави визначити глобальною стратегією перекладу оповідання очуження. Така стратегія дозволяє зберегти в перекладі національно-культурну самобутність оригіналу на рівнях змістовнофактуальної інформації та ціннісних орієнтирів. Глобальній ментальній програмі перекладача із пересотворення цілісного мегаконцепту підпорядковані локальні стратегії та тактики, вибір яких зумовлений характером перекладацьких проблем, пов'язаних з відтворенням культурної інформації. Для подолання розбіжностей між мовною й концептуальною картинами світу української та німецької лінгвокультур у перекладі оповідання застосовано локальні стратегії одомашнення й очуження. Одомашнення передбачає орієнтацію на універсальні та специфічні для німецької лінгвокультури мовні знання й культурні стереотипи і полегшення таким чином асоціативно-образного сприйняття німецькомовного читача. Відтворення культурної інформації оповідання в межах очуження дозволяє, по-перше, зберегти локальний і національний колорит твору; по-друге, долучити українські когнітивні структури до мовної картини світу німецької лінгвокультури, що збагачує її новими знаннями, проте вимагає від іiі представників додаткових когнітивних зусиль. Приналежність оповідання до архаїчних текстів зумовило прагнення перекладачів створити художній образ віддаленої від сучасного читача історичної епохи. Для подолання часової дистанції обрано насамперед стратегію архаїзації, проте застосовано також стратегії модернізації та нейтралізації часової дистанції. Кожну локальну стратегію реалізує відповідний комплекс тактик та прийомів. До подальших перспектив дослідження належить вивчення стратегічно-тактичної діяльності перекладача як агента креативної дії щодо відтворення культурної інформації.

\section{СПИСОК ВИКОРИСТАНИХ ДЖЕРЕЛ}

Андрієнко, 2017 - Андрієнко Т. П. Стратегії в інтеракційній моделі перекладу (на матеріалі перекладу англомовних прозових та драматургічних творів українською та російською): дис. ... д-ра филол. наук: 10.02 .16 перекладознавство. Київ, 2017. 499 с.

Арутюнова, 1990 - Арутюнова Н. Д. Метафора и дискурс. Теория метафоры. М., 1990. C. 5-32.

Голубовська, 2004 - Голубовська I.О. Етноспецифічні константи мовної свідомості: автореф. дис. ... д-ра філол. наук: 10.02.15. К., 2004. 27 с.

Евтеев, 2014 - Евтеев С. В. Лингвокультурологическая модель перевода. Вестник Брянского государственного университета: История. Право. Литературоведение. Языкознание. Брянск: РИО БГУ, 2014. № 2. С. 342344.

Павлик, 2012 - Павлик М. Перші ступні русько-українського жіноцтва. Матеріали до електронної хрестоматії з історії української журналістики XIX cm. I уклад. А. М. Волобуєва / за наук. ред. Н. М. Сидоренко. К., 2012. 377 с. URL: http://journlib.univ.kiev.ua/Books/ukrjornXIX.pdf (дата звернення: 13.02.2020).

Кобринська, Пчілка, 1887 - Кобринська Н., Пчілка О. Перший вінок: жіночий альманах О. Перший вінок : жіночий альманах / виданий коштом і заходом Наталії Кобринської і Олени Пчілки. Львів: друкарня Товариства ім. Шевченка, 1887. - 464 c. URL: https://elib.nlu.org.ua/view.html?id=10277 (дата звернення: 15.01.2020). 
Редчиць, Багач, 2013 - Редчиць Т. В., Багач І. Г. Застосування культурологічного та когнітивного підходу при перекладі. Наукові пращ̧і Кам'янецььПодільського університету ім. І. Огієнка: Філологічні науки. Випуск 33. Кам'янець-Подільський: Аксіома, 2013. С. 263-268.

Стефаненко, 1990 - Стефаненко T. Этнопсихология. М.: Институт психологии РАН / Академ. проект, 1990. 320 с.

Франко, 1984 - Франко І. Я. Із остатніх десятиліть ХІХ віку. К. : Наукова думка, 1984. - Т. 41. - С. 471-530. (Зібрання творів: у 50 т.).

Bachmann-Medick, 2009 - Bachmann-Medick, D. (2009). Cultural Turns: Neuorientierungen in den Kulturwissenschaften. Reinbek bei Hamburg: Rowohlt.

Bassnett, Lefevere, 1998 - Bassnett S., Lefevere A. (1998). Where are we in Translation Studies? Constructing Cultures. Essays on Literary Translation. Clevedon: Multilingual Matters. P. 1-11.

Prunč, 2011 - Prunč, E. (2011). Entwicklungslinien der Translationswissenschaft. Von den Asymmetrien der Sprachen zu den Asymmetrien der Macht. Berlin: Frank \& Timme.

Roschkewytsch, 2019 - Roschkewytsch, M. (2019). Das Schicksal lag in Gottes Hand. Schwester, leg die Flügel an! Alla Paslawska; Hildegard Kainzbauer; Alois Woldan (Hrsg.). Lviv, S. 39-52.

Schäffner, 1999 - Schäffner, Ch. (1999). Metaphern. Handbuch Translation. Mary SnellHornby, Paul Kußmaul, Peter A. Schmitt (Hrsg.). Tübingen: Stauffenburg. S. 280-284.

Zybatow, 2011 - Zybatow, L. N. (2011). Metaphern, Metaphernmodelle und metaphorische Abbildungsstereotypen im Vergleich und in der Übersetzung. Studia Translatorica: Translationswissenschaft und ihre Zusammenhänge 4. Hrsg. von Z. Bohušova u. a. Dresden - Wrocław. S. 43-62.

\section{REFERENCES}

Andriienko, 2017 - Andriienko, T. P. (2017). Stratehii v interaktsiinii modeli perekladu (na materiali perekladu anhlomovnykh prozovykh ta dramaturhichnykh tvoriv ukrainskoiu ta rosiiskoiu) [Strategies in the interaction model of translation (based on the translation of English prose and drama works into Ukrainian and Russian)]. D.Sc. Dissertation. Kyiv [in Ukrainian]

Arutiunova, 1990 - Arutiunova, N.D. (1990). Metafora i diskurs [Metaphor and discourse] In: Teoryia metafory. Moscow, pp. 5-32 [in Russian]

Bachmann-Medick, 2009 - Bachmann-Medick, D. (2009). Cultural Turns: Neuorientierungen in den Kulturwissenschaften. Reinbek bei Hamburg: Rowohlt.

Bassnett, Lefevere, 1998 - Bassnett S., Lefevere A. (1998). Where are we in Translation Studies? Constructing Cultures. Essays on Literary Translation. Clevedon: Multilingual Matters. P. 1-11.

Evteev, 2014 - Evteev, S. V. (2014). Lynhvokulturolohycheskaia model perevoda [The linguo-cultural model of translation] In: Vestnyk Brianskoho hosudarstvennoho unyversyteta: Ystoryia. Pravo. Lyteraturovedenye. Yazykoznanye. Briansk: RYO BHU. no. 2, pp. 342-344 [in Russian]

Franko, 1984 - Franko, I. Z ostannich desjatelitj XIX v. [From the last decades of the XIX century]. Kyiv: Naukova dumka, vol. 41, pp. 471-530 [in Ukrainian]

Holubovska, 2004 - Holubovska, I.O. (2004). Etnospetsyfichni konstanty movnoi svidomosti [Ethnospecific constants of linguistic consciousness]. Abstract of the D.Sc. Dissertation. Kyiv [in Ukrainian]

Kobrynska, Pchilka, 1887 - Kobrynska, N., Pchilka, O. ed. (1887). Pershyi vinok : zhinochyi almanakh [The first wreath: women's almanac]. Retrieved from

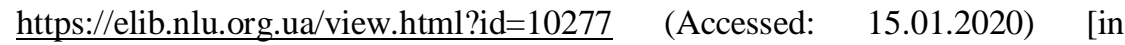
Ukrainian] 
Pavlyk, 2012 - Pavlyk, M. (2012). Pershi stupni rusko-ukrainskoho zhinotstva [The first steps of Ruthenian-Ukrainian women] In: Materialy do elektronnoi khrestomatii $z$ istorii ukrainskoi zhurnalistyky XIX st. Kyiv. Retrieved from http://journlib.univ.kiev.ua/Books/ukrjornXIX.pdf (Accessed: 13.02.2020) [in Ukrainian]

Prunč, 2011 - Prunč, E. (2011). Entwicklungslinien der Translationswissenschaft. Von den Asymmetrien der Sprachen zu den Asymmetrien der Macht. Berlin: Frank \& Timme [in Germany]

Redchyts, Bahach, 2013 - Redchyts, T. V., Bahach, I. H. (2013). Zastosuvannia kulturolohichnoho ta kohnityvnoho pidkhodu pry perekladi [The application of culturological and cognitive approach in translation]. In: Naukovi pratsi Kamianets- Podilskoho universytetu im. I.Ohiienka: Filolohichni nauky. Kam'yanecz`'Podil`s`ky`j: Aksioma, Issue 33, pp. 263-268 [in Ukrainian]

Roschkewytsch, 2019 - Roschkewytsch, M. (2019). Das Schicksal lag in Gottes Hand. Schwester, leg die Flügel an! Alla Paslawska; Hildegard Kainzbauer; Alois Woldan (Hrsg.). Lviv, S. 39-52 [in Germany]

Schäffner, 1999 - Schäffner, Ch. (1999). Metaphern. Handbuch Translation. Mary SnellHornby, Paul Kußmaul, Peter A. Schmitt (Hrsg.). Tübingen: Stauffenburg. S. 280-284 [in Germany]

Stefanenko, 1990 - Stefanenko, T. (1990). Etnopsykholohyia [Ethnopsychology]. Moscow: Ynstytut psykholohyy RAN / Akadem. Proekt [in Russian]

Zybatow, 2011 - Zybatow, L. N. (2011). Metaphern, Metaphernmodelle und metaphorische Abbildungsstereotypen im Vergleich und in der Übersetzung. Studia Translatorica: Translationswissenschaft und ihre Zusammenhänge 4. Hrsg. von Z. Bohušova u. a. Dresden - Wrocław. S. 43-62 [in Germany]

Received: 30 August, 2020 